\title{
Assessment of metal leachability and toxicity from sediment potentially stored on land
}

\author{
A Baran ${ }^{1 *}$, M Tarnawski $^{2}$ and B Michalec ${ }^{2}$ \\ 'Department of Agricultural and Environmental Chemistry, University of Agriculture, Mickiewicza Ave 21, 31-120 Cracow, Poland \\ ${ }^{2}$ Department of Hydraulic Engineering and Geotechnics, University of Agriculture, Mickiewicza Ave 24/28, 30-059 Cracow, Poland
}

\begin{abstract}
The aim of this study was to assess the toxicity and metal leachability from three dredged bottom sediments potentially stored on land. Washing out was conducted at a sediment dry mass to water mass ratio of 1:10. The method relies on washing out pollutants from the examined sample using water with third degree of purity in static/quasi-dynamic conditions. The investigations comprised three 27 - $\mathrm{h}$ washing out cycles, including leaching in static conditions $(19 \mathrm{~h})$ and shaking $(8 \mathrm{~h})$. Bottom sediments are complex matrices; therefore laboratory tests cannot always reflect changes in physicochemical properties, which can potentially take place after a longer period of time. In spite of this, static-dynamic tests conducted under laboratory conditions provide information which enables a rough estimation of the potential threat posed by the studied sediment to the environment, at a given time. It was demonstrated that the leachability of metals during storage of polluted (Rybnik, Rzeszów) or unpolluted (Narożniki) bottom sediments does not pose a hazard to the environment. The Microtox test showed low toxicity of test water extracts. Considering their final destination, the potential and actual environmental hazards which the extracted bottom deposits pose should be assessed by determining the leachability of metals.
\end{abstract}

Keywords: dredged sediments, metals, leaching, toxicity, Microtox

\section{INTRODUCTION}

Sediments accumulated in water reservoirs constitute a very important part of ecosystems, and play a crucial role in their functioning, as well as in element cycling among individual components of the water-ground system (Barbosa and De Almeida, 2001). The structure of sediments makes them a natural geosorbent, in which pollutants introduced to the water environment accumulate. Dredging water reservoirs is a commonly used measure, allowing their maintenance in a proper condition so that they fulfil their economic functions (Mamindy-Pajany et al., 2010; Szalińska, 2011; Baran and Tarnawski, 2013). The data derived from the Sed-Net (European Sediment Network) monitoring programme reveals that annually approx. $100-200 \times 10^{6} \mathrm{~m}^{3}$ of sediments is generated in Europe, whereas, by comparison, in the United States this is $400 \times 10^{6} \mathrm{~m}^{3}$ annually. In many countries dredged sediments are regarded as waste, and, depending on their chemical composition, are considered either as material fit for reuse in the environment without limitations, or as material to be used but with some limitations. Sediments classified as polluted are destined for cleaning or deposition on landfill sites (Linkov et al., 2002; Perrodin et al., 2006). Sediment deposition on land in atmospheric conditions poses numerous hazards related to protection of the natural environment (Czerniawska-Kusza and Kusza, 2011; Mamindy-Pajany et al., 2011, Caille et al., 2012). Numerous physical, chemical and biological processes which take place under the influence of atmospheric conditions and in the presence of microorganisms cause ageing of deposited material, weathering and leaching (Tack et al., 1996; Piou et al., 2009). Leaching of harmful substances, including metals, from

\footnotetext{
To whom all correspondence should be addressed.

¿ +481266243 52, fax: +48126624341

e-mail: baranaga1@wp.pl; Agnieszka.Baran@ur.krakow.pl

Received: 18 July 2014; accepted in revised form 19 August 2015
}

sediments deposited on land is particularly dangerous and may lead to the pollution of surface and groundwater, as well as soils. The occurrence of metals in sediments is extremely important from an ecological point of view, because some metals are toxic $(\mathrm{Pb}, \mathrm{Cd}, \mathrm{Hg})$, and all in excess are harmful to living organisms (Baran and Tarnawski, 2013; 2015). An important feature which distinguishes metals from other undesirable substances is the fact that they do not undergo biodegradation but only biotransformation (Singh et al., 2005; Yuvanatemiya and Boyd, 2006; Rabajczyk, 2011; Baran and Tarnawski, 2015). Metals may be immobilized in the sediments for a long time, but in variable atmospheric conditions they may be easily leached from the sediments and pose a hazard of returning the element to cycling in nature (Rabajczyk, 2011; Baran et al., 2011; Baran and Tarnawski, 2013). Mobility of pollutants leached from the sediments, expressed as their susceptibility to leaching from the matrix, is the most important feature of waste from an ecological perspective, and which, apart from composition, is taken into consideration in the assessment of the waste's harmfulness to the environment (Hardaway et al., 1999). Leachability is a tendency to form harmful leachates in contact with water, and is an important feature of stored wastes (Stephens et al., 2001). Chemical analyses of water extracts are conducted in order to estimate the hazard of various wastes.

The aim of the presented investigations was: (i) to assess the metal leachability from dredged bottom sediments, and (ii) to evaluate the toxicity of water extracts prepared from bottom sediment potentially stored on land.

\section{MATERIALS AND METHODS}

\section{Study area}

Bottom sediments for the analysis were sampled from 3 water reservoirs in Poland: the Rzeszów Reservoir, the Narożniki Reservoir and the Rybnik Reservoir (Fig. 1). 


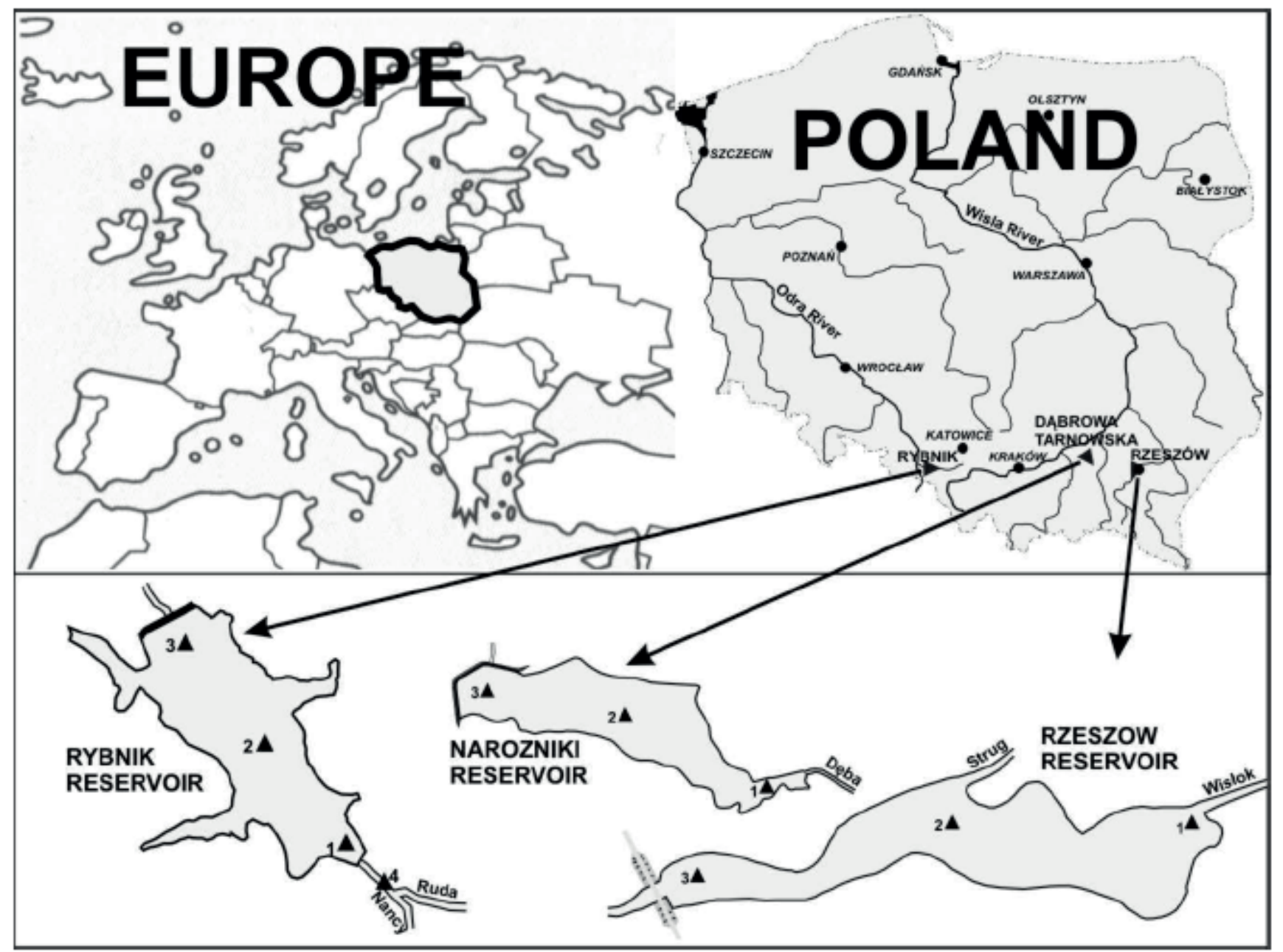

Figure 1

Bottom sediment sampling sites

The Rzeszów water reservoir on the Wisłok River was constructed in 1973. Its main objectives include: enabling water intake for the Rzeszów city water supply system, flood control, and creating conditions for recreation for the inhabitants of the city and its surroundings. The reservoir's initial capacity was $1.8 \mathrm{M} \mathrm{m}^{3}$; the impoundment area is $68.2 \mathrm{ha}$. The reservoir has an elongated shape, and is approx. $6.7 \mathrm{~km}$ long with variable width, from $35 \mathrm{~m}$ in the backwater area to $600 \mathrm{~m}$ in the central part. Measurements conducted after 14 years of reservoir operation revealed that its capacity had diminished by approx. $66 \%$, with a loss of 18.5 ha of impoundment area, constituting permanently or periodically overgrown islands and shallows. The reservoir was unsuccessfully deepened and modernized in the 80 s and 90s. It has been estimated that currently the spontaneously forming islands and shallows cover over 30 ha of the reservoir area. Dredging works have been conducted since February 2010 with breaks for bird breeding periods. The obtained material is deposited in the riparian areas and after dewatering is to be managed for technical and environmental purposes.

The Rybnik reservoir, situated on the Ruda River, and impounding a catchment with an area of $308 \mathrm{~km}^{2}$, was commissioned for operation in 1972. The main function of the reservoir is as a source of cooling water for the Rybnik Power Plant JSC, and for flood control. The reservoir also provides benefits as a site for recreation and as waterfowl habitat. The reservoir is 7 $\mathrm{km}$ long. Its initial capacity was $25.8 \mathrm{M} \mathrm{m}^{3}$ in the impoundment area together with lateral impoundments of 555 ha. According to the data provided by IMGW-PIB (Institute of Meteorology and Water Management - National Research Institute) the Rybnik reservoir is silting up very slowly, as after 27 years of operation the level of silting was $0.74 \%$ and after 36 years this increased to only $0.97 \%$. The pollution of bottom sediments poses a serious hazard to the environment due to industrial character of the Ruda River catchment. The sediments contain elevated metal contents, with the most heavily polluted section being a zone of 150 ha in the north-western part of the reservoir. The maximum metal concentrations determined in this area were as follows (mg.kg $\left.{ }^{-1} \mathrm{~d} . \mathrm{m}\right): 30 \mathrm{mg} \mathrm{Cd}, 55 \mathrm{mg} \mathrm{Ni}, 130$ mg Cr, $160 \mathrm{mg} \mathrm{Pb}, 1000 \mathrm{mg} \mathrm{Cu}$ and $1300 \mathrm{mg} \mathrm{Zn} \mathrm{(Kostecki} \mathrm{and}$ Kowalski, 2007).

The water reservoir in Narożniki is situated on the Dęba stream. The reservoir encloses a catchment with an area of only $25 \mathrm{~m}^{2}$. The stream catchment is poorly industrialized: $50 \%$ afforested area, 35\% agricultural lands, $15 \%$ grasslands and built-up area. The Narożniki reservoir, with a capacity of $283.8 \times 10^{3} \mathrm{~m}^{3}$, was commissioned for operation in 2001 . The reservoir is $1030 \mathrm{~m}$ in length, with a mean depth of $1.2 \mathrm{~m}$. The impoundment area is $24 \mathrm{ha}$. The main purposes of the reservoir comprise water retention, evening out of flows and reduction of 
the height of flood waves. Moreover, the reservoir fulfils a recreational function. After 4 years of reservoir operation, waste capacity was $1645.7 \mathrm{~m}^{3}$ (Michalec et al., 2006). The computed level of silting is only $0.58 \%$. This low rate of silting ensures reservoir longevity, and is due to the small amount of bedload transported from the small and largely forested catchment.

\section{Sampling method}

The sediments were sampled in all reservoirs according to the following procedure. Three zones were established in the reservoir bowl: inlet (backwater), middle, and outlet (at the dam wall) (Fig. 1). Five or six samples were collected from each zone and mixed to average the properties of sediment samples representing individual zones. The samples were collected from below the water-sediment interface with an Ekman grab sampler. In justified cases, underwater sampling was conducted, as in case of the Rybnik reservoir, whose sediments contain a lot of woody debris which prevents closing of the sampler jaws. The sediments were collected from the $0-20 \mathrm{~cm}$ layer and stored at $4^{\circ} \mathrm{C}$ until use.

\section{Chemical analysis}

The sediments were characterized for general parameters such as granular composition, $\mathrm{pH}$ and organic matter content. Granulometric composition was determined according to PN-EN ISO 14 688-1; 2006. The $\mathrm{pH}$ was measured at a 1:2.5 bottom sediment:liquid ratio with $1 \mathrm{~mol} \cdot \mathrm{dm}^{-3} \mathrm{KCl}$, according to PN-ISO 10390:1997. Organic matter content was determined by loss on ignition for $8 \mathrm{~h}$ at $450^{\circ} \mathrm{C}$. Total metal content was also assessed in the sediments. Total element content in the sediments was assessed after hot digestion in a mixture of $\mathrm{HNO}_{3}$ and $\mathrm{HClO}_{3}$ (3:2) acids. Contents of metals were analysed using the ICP-OES method on an Optima 7300 DV (Perkin-Elmer). The accuracy of the performed analyses was tested using reference material CRM16-050. Good agreement between the determined and certified values was obtained. The recoveries of CRM16-050 were between 90 and 103\% for all metals.

The leachability of metals from the bottom sediments was evaluated according to the Polish standard PN-Z-15009. This method relies on washing out pollutants from the examined sample using water with third degree of purity in static/quasidynamic conditions. Washing out tests conducted under static conditions allow an assessment of a potential release of metals. Dynamic tests enable one to assess the dynamics of the release of metals under laboratory conditions, as distinct from chemical extraction (speciation) which provides information on forms of bonding and kinetics of release of metals under field conditions; lack of such information is a limitation to this method. The results obtained in this way do not reflect the total content of a given metal (which could become mobilized in the environment) in the sediments. Sediments are complex matrices, therefore laboratory tests cannot always reflect changes in physicochemical properties, which can take place after a longer period of time. In spite of this, static-dynamic tests conducted under laboratory conditions provide information which enables a rough estimation of a potential threat posed by the studied sediment to the environment at a given time. At this point it should be noted that other authors have used a method based on preparing water extracts from dredged bottom sediments to determine the leachability of metals from these sediments (e.g. Stephens et al., 2001; Sahuguillo et al.,
2002; Sabra et al., 2012). The washing out was conducted at a sediment dry mass to water mass ratio of 1:10. The investigations comprised three 27 -h washing out cycles, including leaching in static conditions (19 h) and shaking $(8 \mathrm{~h})$. Ten grams $(10 \mathrm{~g})$ of the sediments were weighed out. The analyses were conducted in 3 replicates for each sediment sample $(n=27)$. The sample was placed in a conical flask and $100 \mathrm{~cm}^{3}$ of distilled water was added. After $1 \mathrm{~h}$, the flask was corked and shaken for $4 \mathrm{~h}$. Then, the flask was opened and left for $16 \mathrm{~h}$. Subsequently, the flask was shaken again for $4 \mathrm{~h}$ and left for $2 \mathrm{~h}$. After being centrifuged, the eluate was transferred into a $100 \mathrm{~cm}^{3}$ measuring flask. The sediment was treated with another identical portion of distilled water and washed again. The procedure was repeated so that 3 water extracts were obtained in total. Contents of $\mathrm{Zn}, \mathrm{Cu}, \mathrm{Ni}, \mathrm{Cd}, \mathrm{Pb}$ and $\mathrm{Cr}$ were assessed using an ICP OES (Perkin-Elmer Optima 7300 DV). The content of the studied metals in individual water extracts was computed in grams per kilogram of dry sediment according to the following formula:

$$
q_{1,2,3}=\frac{V_{1,2,3} \times C_{1,2,3}}{m}
$$

where: $q_{1,2,3}$ is the content of metal in the first, second or third water extract; $V_{1,2,3}$ is the volume of water extract obtained in the first, second or third washing out in $\mathrm{cm}^{3}, c_{1,2,3}$ is the concentration of the studied element in the first, second or third water extract in $\mathrm{mg} / \mathrm{cm}^{3}, m$ is the dry sample mass used for the analyses, expressed in $\mathrm{g}$. The metal content of the water extract was computed after summing up the results obtained in all washing out cycles. The obtained results were elaborated statistically using the Statistica 10 (StatSoft, US) package.

\section{Ecotoxicity test: Microtox}

Acute toxicity of water extracts was tested on Vibrio fischeri bacteria using an M 500 Analyzer. A characteristic of $V$. fischeri is the allocation of a major part of their metabolic energy to luminescence. Luminescent bacteria generate light within the visible spectrum as an effect of their normal metabolic processes. Any change in metabolism caused by a toxic substance causes a change in the produced luminosity. The change is directly proportional to the biological activity of a given substance. Luminescence was measured before and after incubation of bacterial suspension with the analysed sample. The 15-min luminescence inhibition test with $V$. fischeri was performed according to the method of Microbics Corporation (Microbics, 1992).

\section{RESULTS}

\section{Chemical analysis}

The physicochemical characteristics and the total metal content of the bottom sediments are presented in Table 1. Bottom sediments were characterized by neutral (Rzeszów), slightly acidic (Rybnik) and acidic pH (Narożniki). The highest content of organic matter was found in the bottom sediments of the Rybnik reservoir (23.2-37.7\%), and the lowest in the bottom sediments of the Narożniki reservoir (0.14-3.1\%). The highest total content of metals was found in the bottom sediments of the Rybnik reservoir, and was lower in the bottom sediments of the Rzeszów reservoir, and lowest in the bottom sediments of the Narożniki reservoir (Table 1). Granulometric composition of the bottom sediments is presented in Fig. 2. 
TABLE 1

Physical and chemical characterization of the bottom sediments

\begin{tabular}{|c|c|c|c|c|c|c|c|c|c|}
\hline \multirow{2}{*}{\multicolumn{2}{|c|}{ Sediment }} & \multirow[t]{2}{*}{ pH } & \multirow{2}{*}{$\begin{array}{c}\begin{array}{c}\text { Org. } \\
\text { matter }\end{array} \\
\%\end{array}$} & $\mathbf{Z n}$ & $\mathrm{Cu}$ & $\mathrm{Ni}$ & $\mathbf{P b}$ & Cd & $\mathrm{Cr}$ \\
\hline & & & & \multicolumn{6}{|c|}{$\mathbf{m g} \cdot \mathbf{k g}^{-1}$ dry mass } \\
\hline \multirow[b]{2}{*}{ Rzeszów } & Mean & 7.3 & 6.7 & 106.8 & 22.8 & 35.2 & 19.6 & 4.47 & 35.1 \\
\hline & $\begin{array}{l}\text { Min. } \\
\text { Max }\end{array}$ & $\begin{array}{l}6.9 \\
7.4\end{array}$ & $\begin{array}{l}3.6 \\
7.2\end{array}$ & $\begin{array}{c}72.2 \\
126.3\end{array}$ & $\begin{array}{l}14.7 \\
25.9\end{array}$ & $\begin{array}{l}25.7 \\
45.5\end{array}$ & $\begin{array}{l}10.3 \\
206\end{array}$ & $\begin{array}{l}0.45 \\
14.9\end{array}$ & $\begin{array}{l}26.9 \\
39.4\end{array}$ \\
\hline \multirow[b]{2}{*}{ Rybnik } & Mean & 6.3 & 26.5 & 902.3 & 286.2 & 39.9 & 84.45 & 7.53 & 125.3 \\
\hline & $\begin{array}{l}\text { Min. } \\
\text { Max }\end{array}$ & $\begin{array}{l}6.0 \\
6.9\end{array}$ & $\begin{array}{l}23.2 \\
37.7\end{array}$ & $\begin{array}{c}744 \\
1180\end{array}$ & $\begin{array}{l}79.7 \\
639\end{array}$ & $\begin{array}{l}32.8 \\
43.1\end{array}$ & $\begin{array}{c}60.1 \\
113\end{array}$ & $\begin{array}{l}5.25 \\
13.0\end{array}$ & $\begin{array}{c}58.2 \\
167.3\end{array}$ \\
\hline \multirow[b]{2}{*}{ Narożniki } & Mean & 5.3 & 0.76 & 48.2 & 5.13 & 14.5 & 8.40 & 0.35 & 19.6 \\
\hline & $\begin{array}{l}\text { Min. } \\
\text { Max }\end{array}$ & $\begin{array}{l}5.2 \\
5.6\end{array}$ & $\begin{array}{c}0.14 \\
3.1\end{array}$ & $\begin{array}{l}26.1 \\
92.1\end{array}$ & $\begin{array}{l}2.45 \\
14.9\end{array}$ & $\begin{array}{c}1.2 \\
19.4\end{array}$ & $\begin{array}{l}4.30 \\
23.4\end{array}$ & $\begin{array}{c}0 \\
0.55\end{array}$ & $\begin{array}{l}2.20 \\
30.0\end{array}$ \\
\hline
\end{tabular}

\begin{tabular}{|c|c|c|c|c|c|c|c|}
\hline \multicolumn{8}{|c|}{$\begin{array}{c}\text { TABLE } 2 \\
\text { Content of metals in water extracts from the bottom sediment }\end{array}$} \\
\hline \multirow{2}{*}{ Metals } & \multirow{2}{*}{ Sediment } & Zone 1 & Zone 2 & Zone 3 & Mean & \multirow{2}{*}{$\begin{array}{c}\text { RSD* } \\
\%\end{array}$} & \multirow{2}{*}{$\begin{array}{l}\text { Metal leaching } \\
\text { coefficient }\end{array}$} \\
\hline & & \multicolumn{4}{|c|}{$\mathbf{m g} \cdot \mathbf{k g}^{-1}$} & & \\
\hline \multirow{3}{*}{$\mathrm{Zn}$} & Rzeszów & 5.45 & 1.11 & 1.21 & 2.59 & 96 & 0.02 \\
\hline & Rybnik & 11.74 & 8.83 & 5.91 & 8.83 & 33 & 0.01 \\
\hline & Narożniki & 1.73 & 1.15 & 5.13 & 2.67 & 81 & 0.06 \\
\hline \multirow{3}{*}{$\mathrm{Cu}$} & Rzeszów & 4.17 & 0.87 & 0.57 & 1.87 & 94 & 0.08 \\
\hline & Rybnik & 3.5 & 3.65 & 0.86 & 2.67 & 59 & 0.01 \\
\hline & Narożniki & 0.81 & 0.29 & 0.33 & 0.48 & 60 & 0.09 \\
\hline \multirow{3}{*}{$\mathrm{Ni}$} & Rzeszów & 3.12 & 0.55 & 0.47 & 1.38 & 99 & 0.04 \\
\hline & Rybnik & 1.49 & 1.04 & 1.38 & 1.30 & 18 & 0.03 \\
\hline & Narożniki & 0.52 & 0.49 & 0.93 & 0.65 & 72 & 0.04 \\
\hline \multirow{3}{*}{$\mathrm{Pb}$} & Rzeszów & 2.19 & 0.97 & 0.69 & 1.28 & 92 & 0.07 \\
\hline & Rybnik & 2.32 & 0.82 & 0.91 & 1.35 & 62 & 0.02 \\
\hline & Narożniki & 0.49 & 0.51 & 0.73 & 0.58 & 22 & 0.07 \\
\hline \multirow{3}{*}{$\mathrm{Cd}$} & Rzeszów & 2.14 & 0.30 & 0.13 & 0.86 & 68 & 0.19 \\
\hline & Rybnik & 0.10 & 0.05 & 0.05 & 0.07 & 43 & 0.01 \\
\hline & Narożniki & 0.03 & 0.02 & 0.03 & 0.03 & 50 & 0.09 \\
\hline \multirow{3}{*}{$\mathrm{Cr}$} & Rzeszów & 3.15 & 0.33 & 0.35 & 1.28 & 88 & 0.04 \\
\hline & Rybnik & 0.88 & 0.55 & 1.38 & 0.94 & 45 & 0.01 \\
\hline & Narożniki & 0.58 & 0.55 & 2.58 & 1.24 & 94 & 0.06 \\
\hline
\end{tabular}

${ }^{\star} \mathrm{RSD}$ relative standard deviation

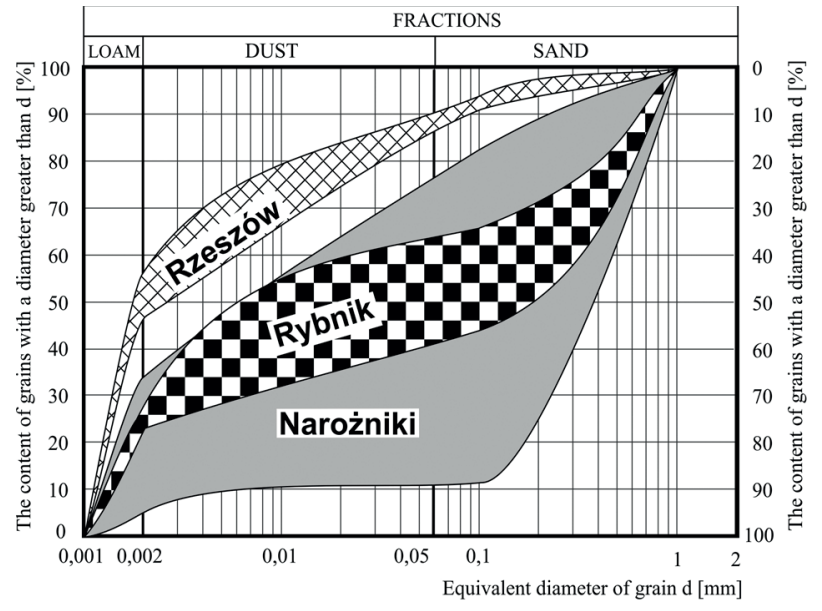

Figure 2

Granulometric composition of sediments
Results obtained by means of a water extracts method do not reflect the total content of a given element in wastes which may become mobilized in the environment. However, they allow an approximate estimation of hazard posed by the waste material. Metal contents assessed in water extracts prepared from the sediments are presented in Table 2.

$\mathrm{Zn}$ concentrations in water extracts ranged from 1.11 to $11.74 \mathrm{mg} \cdot \mathrm{kg}^{-1}$; $\mathrm{Cu}$ from 0.29 to $4.17 \mathrm{mg} \cdot \mathrm{kg}^{-1}$; $\mathrm{Ni}$ from 0.46 to $3.12 \mathrm{mg} \cdot \mathrm{kg}^{-1} ; \mathrm{Pb}$ from 0.49 to $2.19 \mathrm{mg} \cdot \mathrm{kg}^{-1}$, Cd from 0.02 to $2.14 \mathrm{mg} \cdot \mathrm{kg}^{-1}$, and $\mathrm{Cr}$ from 0.33 to $3.15 \mathrm{mg} \cdot \mathrm{kg}^{-1}$. The highest mean content of $\mathrm{Zn}, \mathrm{Cu}$ and $\mathrm{Pb}$ was assessed in water extracts prepared from the Rybnik bottom sediment, whereas $\mathrm{Ni}$, $\mathrm{Cr}$ and $\mathrm{Cd}$ were highest in water extracts from the Rzeszów sediment. Water extracts from the Narożniki bottom deposits most often revealed the lowest content of the studied metals (Table 2). The obtained results point to a considerable diversification of metal concentrations in water extracts within a single bottom deposit, in the first instance depending on the 
sampling zone. The greatest diversification in metal content in the obtained extracts was demonstrated for the bottom deposits sampled from the Rzeszów reservoir, as evidenced by high coefficients of variation. Moreover, the highest metal content in the extracts obtained from the analysed bottom sediments was found in Zone I (backwater). Variation in the leachability of metals from sediments, depending on the washing out cycle, is presented in Fig. 3.

In the sediment from Rzeszów, the leachability of individual metals was at a similar level, as evidenced by significant positive correlations between different metals (Fig. 3A, Table 3). After $54 \mathrm{~h}$ (cycle I+II), $74 \%$ of $\mathrm{Cr}, 76 \%$ of $\mathrm{Zn}$ and Ni, $77 \%$ of $\mathrm{Pb}$ and $\mathrm{Cd}$ and $82 \%$ of $\mathrm{Cu}$ were washed out, relative to the total metal content assessed in the water extracts (Fig. 3A). Considerable variability in the leachability of individual metals was revealed in the bottom sediment from Rybnik (Fig. 3B, Table 3). In this sediment, Cd was washed out the most rapidly $(100 \%)$ and $\mathrm{Pb}$ the most slowly $-41 \%$ of the total content assessed after 3 washing out cycles $(81 \mathrm{~h})$. The leachability of the remaining elements after $54 \mathrm{~h}$ ranged from $73 \%(\mathrm{Cu})$ to $84 \%(\mathrm{Cr})$ of their total content assessed in water extracts. In the bottom sediment from Narożniki, the leachability of most elements showed a similar trend (Fig. 3C, Table 3). For most metals, over $50 \%$ was washed out in the 2 nd cycle, i.e., after $54 \mathrm{~h}$. Only in the case of Cd was $100 \%$ assessed in the extract obtained after $27 \mathrm{~h}$ (first washing out cycle).

The metal leaching coefficient from the bottom sediments was computed as a ratio of the element's concentration in a water extract to its total content in sediment (Table 2). For this study, the value of the leaching coefficient was between 0.01 and 0.06 for $\mathrm{Zn}, 0.01$ and 0.09 for $\mathrm{Cu}, 0.033$ and 0.045 for $\mathrm{Ni}$, 0.02 and 0.07 for $\mathrm{Pb}, 0.01$ and 0.09 for $\mathrm{Cd}$, and between 0.01 and 0.06 for $\mathrm{Cr}$ (Table 2). The presented data show that the greatest quantities of $\mathrm{Zn}, \mathrm{Cu}, \mathrm{Ni}, \mathrm{Pb}$ and $\mathrm{Cr}$ should be released into the environment from the bottom sediment of the Narożniki reservoir, whereas the greatest quantity of $\mathrm{Cd}$ should be released from the sediment of the Rzeszów reservoir, according to the metal leaching coefficients for these sediments (Table 2). The lowest metal leaching coefficients were obtained for the sediment from Rybnik. Considering $\mathrm{Zn}, \mathrm{Cu}, \mathrm{Ni}, \mathrm{Pb}$ and $\mathrm{Cr}$ concentrations, sediments from the Rzeszów reservoir were placed in the middle. Poor solubility of heavy metals in the bottom deposits from the Rybnik and Rzeszów reservoirs is connected with low hydrogen ion concentration $(\mathrm{pH})$ in these sediments, with a $\mathrm{pH}$ of 6.3 and 7.3, respectively, and high content of organic matter, particularly in the Rybnik reservoir (26.5\%) and the Rzeszów reservoir (6.7\%).

\section{Water extract ecotoxicity}

The results of the toxicity tests on water extracts prepared from sediments are shown in Table 4. The highest luminescence inhibition of $V$. fischeri was detected after $27 \mathrm{~h}$ of leaching (I cycle), at 15 to 49\% (Rzeszów), 33 to 54\% (Rybnik) and 11 to $27 \%$ (Narożniki). Water extracts prepared from the Rybnik reservoir sediments showed the highest toxicity. These extracts caused luminescence inhibition of $V$. fischeri ranging from 4 (cycle III) to $54 \%$ (I cycle). It was found that the toxicity of water extracts for $V$. fischeri generally decreased with successive cycles of washing. After the third cycle of leaching (after $81 \mathrm{~h}$ ), the obtained water extracts showed low toxicity (Rybnik) or the lack of it. Numerous studies have found that a toxicity effect of $\mathrm{PE}<20 \%$ indicates no significant toxic effects, while $20 \% \leq \mathrm{PE}<50 \%$ indicates low toxicity (Persoon et al., 2003; Mankiewicz-Boczek et al., 2008). Additionally, a statistical analysis was performed aiming to determine the correlation between the metal content in water extracts, and the toxicity results (Table 3 ). The calculated positive correlation coefficients show that the higher the metal content in the water extract, the higher its toxicity. Negative values indicate that the increase in the concentration of metal does not affect the increase in toxicity of test extracts. The results showed that 9 out of 27 samples ( $33 \%$ of the total) confirm the above relationship. Most of these were recorded for water extracts prepared from the Rybnik reservoir sediments (Table 3), which confirms the relatively high toxicity of the extracts analysed (Table 4).
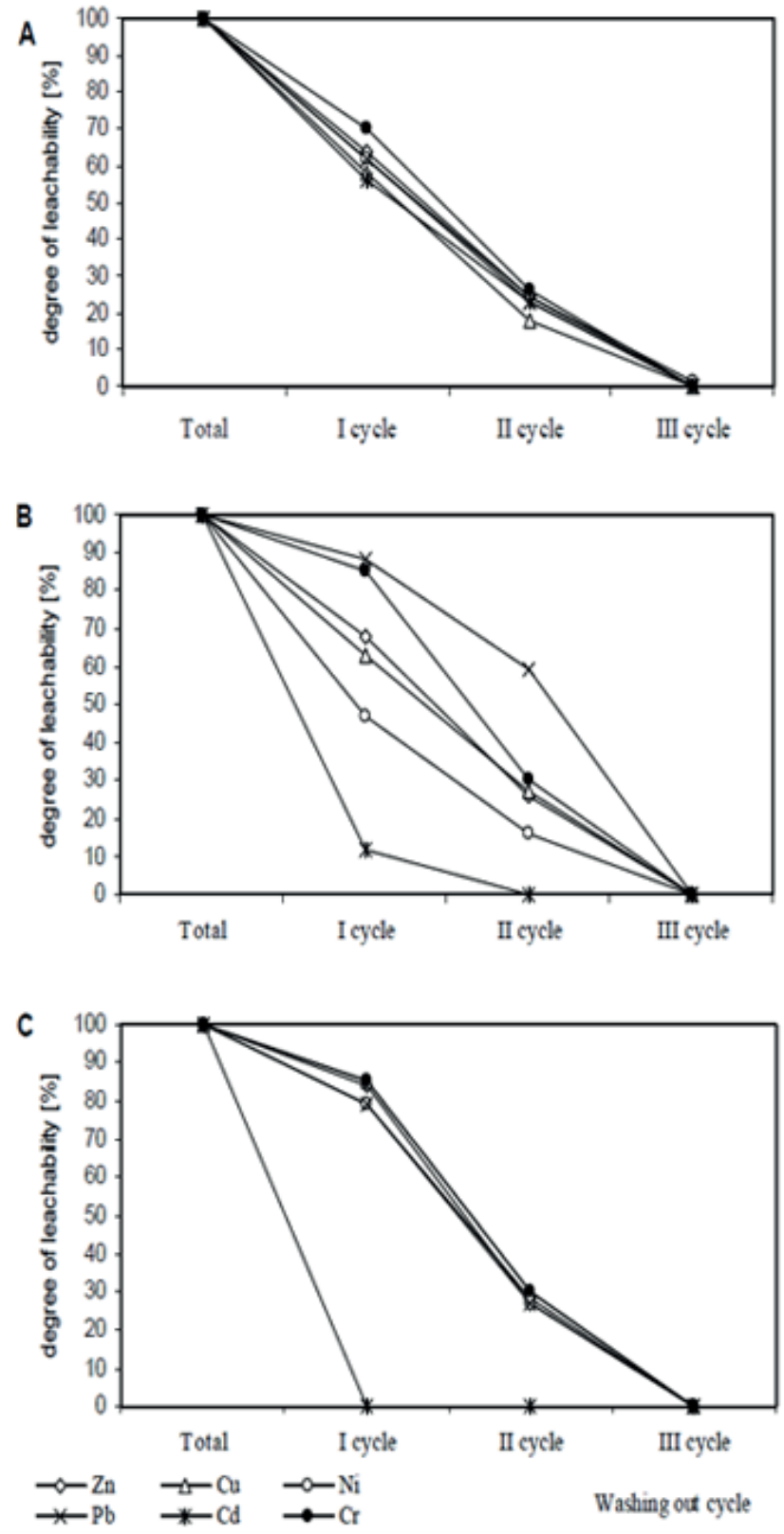

Figure 3

The degree of leachability of metals depending on the washing out cycle: A-Rzeszów, B-Rybnik, C-Narożniki 
TABLE 3

Correlation analysis for metals content in water extracts, and toxicity results

\begin{tabular}{|c|c|c|c|c|c|c|c|c|c|c|c|c|c|c|c|c|c|c|}
\hline & \multicolumn{6}{|c|}{ Rzeszów } & \multicolumn{6}{|c|}{ Rybnik } & \multicolumn{6}{|c|}{ Narożniki } \\
\hline & Zn & $\mathrm{Cu}$ & Zn & $\mathrm{Cu}$ & $\mathbf{N i}$ & $\mathbf{P b}$ & Cd & $\mathrm{Cr}$ & $\mathbf{N i}$ & $\mathbf{P b}$ & Cd & $\mathrm{Cr}$ & Zn & $\mathrm{Cu}$ & $\mathbf{N i}$ & $\mathbf{P b}$ & Cd & $\mathrm{Cr}$ \\
\hline $\mathrm{Cu}$ & $0.97^{\star}$ & & -0.10 & & & & & & & & & & -0.10 & & & & & \\
\hline $\mathrm{Ni}$ & $0.99^{*}$ & $0.97^{\star}$ & $0.89^{*}$ & -0.02 & & & & & & & & & $0.89^{*}$ & -0.02 & & & & \\
\hline $\mathrm{Pb}$ & $0.99^{\star}$ & $0.97^{\star}$ & $0.79^{\star}$ & -0.02 & $0.91^{\star}$ & & & & -0.29 & & & & $0.79^{\star}$ & -0.02 & $0.91^{*}$ & & & \\
\hline $\mathrm{Cd}$ & $0.98^{\star}$ & $0.96^{*}$ & -0.27 & -0.41 & -0.54 & -0.44 & & & $0.73^{\star}$ & -0.24 & & & -0.27 & -0.41 & -0.54 & -0.44 & & \\
\hline $\mathrm{Cr}$ & $0.98^{*}$ & $0.94^{\star}$ & $0.99^{\star}$ & -0.07 & $0.89^{*}$ & $0.77^{\star}$ & -0.35 & & -0.12 & 0.18 & -0.52 & & $0.99^{*}$ & -0.07 & $0.89^{\star}$ & $0.77^{\star}$ & -0.35 & \\
\hline V.f. & -0.21 & -0.09 & -0.32 & -0.31 & -0.58 & -0.55 & $0.77^{\star}$ & -0.37 & $0.78^{\star}$ & 0.15 & $0.65^{\star}$ & -0.15 & -0.32 & -0.31 & -0.58 & -0.55 & $0.77^{\star}$ & -0.37 \\
\hline
\end{tabular}

V.f. - Vibrio fischeri, ${ }^{*}$ Significant at $p<0.05$

\begin{tabular}{|l|c|c|c|c|}
\hline \multicolumn{5}{|c|}{ Toxicity of water extracts to Vibrio fischeri } \\
\hline \multirow{4}{*}{ Sediment } & \multirow{2}{*}{ Zone } & $\mathbf{1 5}$ min luminescence inhibition - PE\% \\
\cline { 3 - 5 } & & $\begin{array}{c}\text { I cycle } \\
\text { after } \mathbf{2 7} \mathbf{~ h}\end{array}$ & $\begin{array}{c}\text { II cycle } \\
\text { after } \mathbf{5 4} \mathbf{~ h}\end{array}$ & $\begin{array}{c}\text { III cycle } \\
\text { after } \mathbf{8 1 ~ h}\end{array}$ \\
\hline \multirow{3}{*}{ Rzeszów } & 1 & 49 & 10 & -20 \\
\cline { 2 - 5 } & 2 & 15 & 0 & -13 \\
\cline { 2 - 5 } & 3 & 45 & 8 & -13 \\
\hline \multirow{3}{*}{ Rybnik } & 1 & 33 & 38 & 19 \\
\cline { 2 - 5 } & 2 & 48 & 14 & 16 \\
\cline { 2 - 5 } & 3 & 54 & 27 & 4 \\
\hline \multirow{3}{*}{ Narożniki } & 1 & 11 & -2 & 0 \\
\cline { 2 - 5 } & 2 & 10 & -5 & 0 \\
\cline { 2 - 5 } & 3 & 27 & -13 & 13 \\
\hline
\end{tabular}

\section{DISCUSSION}

In the presented investigations, the sediments from the bottom of the Rybnik ( $\mathrm{Zn}, \mathrm{Cu}, \mathrm{Cd}$ ) and Rzeszów ( $\mathrm{Pb}$ and $\mathrm{Cd}$ ) reservoirs are polluted with metals in amounts exceeding the standards presented by the Polish regulation on the types and concentrations of substances responsible for causing the output to be regarded as polluted (Journal of Laws no 55 item 498, 2002). Sediments from the Narożniki reservoir are not polluted with metals. This has been confirmed by sediment assessment, according to the Polish Geological Institute (Bojakowska, 2001). Assessment of the effect of sediment components containing metals as pollutants should consider, besides leachability, the so-called ageing effect, depending on the properties of the deposited material. According to many authors, the main factors affecting mobility of metals from bottom sediments include $\mathrm{pH}$ and organic matter content (Peakall and Burger, 2003; Trojanowski et al., 2007). The rate of solution permeating through wastes deposited on landfills is also connected with their grain size distribution. Permeability of solutions seeping through wastes is connected with the finest fraction, which seals the spaces between bigger fractions, and favours reduction of the seepage and therefore element leaching. Clay and silt fractions prevail in the granular composition of the reservoir in Rzeszów, while the Rybnik reservoir is characterized by a greater sand fraction. A wide span of grain size distributions in the analysed samples from the Narożniki reservoir bottom, with a prevailing sand fraction, causes considerable leachability of metals from these sediments. The sediments from

Narożniki reservoir were characterized by a slightly acidic reaction $(\mathrm{pH}=5.3)$ and low content of organic matter (on average $0.76 \%)$. Moreover, sediments with diversified grain size distribution (Rybnik, Narożniki) revealed a greater variability in washing out of individual metals than sediments with unified granular composition (Rzeszów) (Fig. 2). The ecological importance of this process is significant from the time perspective of storage of extracted bottom spoil. The sediment with initial low metal leachability may become more susceptible to atmospheric factors, resulting in increased leachability after a longer storage period. Such a situation may occur in the case of deposition of the sediments from the Narożniki reservoir (Fig. 3C).

Several leaching tests have been applied to study metal remobilisation on uncontaminated and contaminated sediments. In a study by Sahuquillo et al. (2002) mild extractants such as $\mathrm{H}_{2} \mathrm{O}, \mathrm{CaCl}_{2}$ and $\mathrm{NaNO}_{3}$ showed low and similar leaching capacities. Acid $\left(\mathrm{CH}_{3} \mathrm{COOH}\right)$ and complexing (EDTA) agents were more effective in remobilising trace metals from sediments. In the study of Stephens et al. (2001), a simple water extraction procedure was used to investigate changes in metal leachability from dredged canal sediments during dry oxidation. The metal leachability increased over the first 5 weeks of drying and then decreased between Weeks 5 and 12 (e.g. Cd increased from 0.006 to $0.018 \mathrm{mg} \cdot \mathrm{kg}^{-1}$, then decreased to $0.006 \mathrm{mg} \cdot \mathrm{kg}^{-1}$ ) (Stephens et al., 2001). Baran et al. (2011) have shown that metal leachability depends on the extracting solution and the total metal content of sediments.

In summary, it should be stated that while making a decision about the final destination of sediment, it is worth establishing the susceptibility of the heavy metals which they contain to leaching, as well as their toxicity (Devesa-Rey et al., 2010; Baran and Tarnawski, 2013). Metals leaching from the bottom deposits may pose a hazard to soil and water environments; therefore their management through deposition under controlled conditions should be taken into consideration. An important parameter indicating a potential hazard in the deposition of bottom sediments in the terrestrial environment is the leaching coefficient (Prokop et al., 2003). The coefficient indicates the amount and rate of individual element leaching from sediment. This study showed that the highest metal leaching coefficients were obtained for the sediment from Narożniki reservoir and the lowest for the sediment from Rybnik bottom sediments. In research conducted by other authors, the metal leaching coefficient for the bottom deposits was between 0.002 and 0.25 for $\mathrm{Zn}$ and between 0.004 and 0.15 for Cd (Prokop et al., 2003).

However, it should be remembered that various processes leading to changes in bottom sediment properties occur during storage. The presented investigations demonstrated that 
the leachability of metals during storage of polluted (Rybnik, Rzeszów) or unpolluted (Narożniki) bottom sediments does not pose a hazard to the environment. The leachability of the studied metals in relation to their total contents in bottom sediments fluctuated from 1 to $5.5 \%$ for $\mathrm{Zn}, 0.9$ to $0.4 \%$ for $\mathrm{Cu}, 3.3$ to $4.5 \%$ for $\mathrm{Ni}, 1.6$ to $6.9 \%$ for $\mathrm{Pb}, 0.9$ to $19.2 \%$ for $\mathrm{Cd}$ and 0.8 to $6.3 \%$ for $\mathrm{Cr}$. It means that approximately $97 \%$ of $\mathrm{Zn}, 94 \%$ of $\mathrm{Cu}, 96 \%$ of $\mathrm{Ni}, 0.95 \%$ of $\mathrm{Pb}, 90 \%$ of $\mathrm{Cd}$ and $96 \%$ of $\mathrm{Cr}$ may be bound to the organic or residual fractions. The redox potential will change during deposition on landfill sites, which may lead to changes in chemical forms of bound metals in solid phase of the sediments. This process is important when polluted sediments are subjected to oxidation, because it causes a release of extremely toxic metals to the environment. Such a situation may occur during deposition of sediments extracted from the bottom of the Rybnik reservoir. Only in the case of $\mathrm{Cd}$ is there a high potential risk related to this metal leaching during storage of the bottom deposits dredged from Zone I of the Rzeszów reservoir.

\section{CONCLUSION}

The presented study demonstrated that the leachability of metals during storage of polluted (Rybnik, Rzeszów) or unpolluted (Narożniki) bottom sediments does not pose a hazard to the environment. The Microtox test showed low toxicity of test water extracts. Values of metal leaching coefficients from the bottom sediments may be placed in the following order: (i) $\mathrm{Zn}$, $\mathrm{Cu}, \mathrm{Pb}, \mathrm{Cr}, \mathrm{Ni}$ : Narożniki > Rzeszów > Rybnik; (ii) Cd: Rzeszów $>$ Narożniki > Rybnik. Relatively high leachability of metals from bottom sediments of the Narożniki reservoir, despite low total metal concentrations, resulted from physicochemical properties of these sediments. They were characterized by a granulometric composition of sand, slightly acidic reaction and a low content of organic matter. Additionally, it was observed that $\mathrm{Cd}$ was the most rapidly leached metal. Considering their final destination, the potential and actual environmental hazard which is posed by the extracted bottom deposits should be assessed by determining the leachability of the metals.

\section{ACKNOWLEDGEMENTS}

The work was financed by: grant no. N N305 295037 provided by the National Science Centre, and from the subsidy for science DS-3101/KChRiŚ and DS-3322/KIWiG granted by the Polish Ministry of Science and Higher Education.

\section{REFERENCES}

BARAN A and TARNAWSKI M (2013) Phytotoxkit/Phytotestkit and Microtox $^{\oplus}$ as tools for toxicity assessment of sediments. Ecotoxicol. Environ. Saf. 98 19-27.

BARAN A, TARNAWSKI M and JASIEWICZ C (2011) Assessment of the content and solubility of heavy metals in bottom sediments of Chancza reservoir. Ecolog. Chem. Eng. 18 941-950.

BARAN A and TARNAWSKI M (2015) Assessment of heavy metals mobility and toxicity in contaminated sediments by sequential extraction and a battery of bioassays. Ecotoxicology DOI: 10.1007/ s10646-015-1499-4.

BARBOSA MC and DE ALMEIDA M (2001) Dredging and disposal of fine sediments in the state of Rio de Janeiro, Brazil. J. Hazardous Mater. 85 15-38.

BOJAKOWSKA I (2001) Criteria for evaluation of water sediments pollution. Pol. Geol. Rev. 49 213-219 [in Polish].

CAILLE N, TIFFREAU C, LEYVAL C and MOREL JL (2012) Solubility of metals in anoxic sediment during prolonged aeration. Sci. Total Environ. 301 239-250.
CZARNIAWSKA-KUSZA I and KUSZA G (2011) The potential of the Phytotoxkit microbiotest for hazard evaluation of sediments in eutrophic freshwater ecosystem. Environ. Monit. Assess. 179 113-121.

DEVESA-REY R and DÍAZ-FIERROS F BARRAL MT (2010) Trace metals in river bed sediments: an assessment of their partitioning and bioavailability by using multivariate exploratory analysis. $J$. Environ. Manage. 91 2471-2447.

HARDAWAY C, GAUTHREAUX K, SNEDDON J and BECK JN (1999) Evaluation of contaminated sediments by toxicity characteristic leaching procedure extraction technique. Microchem. J. 63 398-404.

KOSTECKI M and KOWALSKI E (2007) Spatial arrangement of heavy metals in the dam-reservoirs sediments in the conditions of anthropomixion. Arch. Environ. Prot. 3 67-81.

LINKOV I, BURMISTROV D, CUR J and BRIDGES TS (2002) Riskbased management of contaminated sediments: consideration of spatial and temporal patterns in exposure modeling. Environ. Sci. Technol. 36 238-246.

MAMINDY-PAJANY Y, HAMER B, ROMÉO M, GÉRET F, GALGANI F, DURMIŠI E, HUREJ C and MARKIER N (2011) The toxicity of composted sediments from Mediterranean ports evaluated by several bioassays. Chemosphere 82 362-369.

MAMINDY-PAJANY Y, LIBRALATO G, ROMÉO M, HUREL C, LOSSO C, GHIRARDINI AV and MARMIER N (2010) Ecotoxicological evaluation of Mediterranean dredged sediment ports based on elutriates with oyster embryotoxicity tests after composting process. Water Res. 44 1986-1994.

MANKIEWICZ-BOCZEK J, NALECZ-JAWECKI G, DROBNIEWSKA A, KAZA M, SUMOROK B, IZYDORCZYK K, ZALEWSKI M and SAWICKI J (2008) Application of microbiotest battery for complete toxicity assessment of rivers. Ecotoxicol. Environ. Saf. 71 830-836.

MICHALEC B, TARNAWSKI M and KUPIEC A (2006) The forecast of silting for small water reservoir. Infrastruct. Ecol. Rural Areas 2 75-84 [in Polish].

MICROBICS (1992) Microtox - Manual. Toxicity Testing Handbook. Microbics, Carlsbad, CA.

PEAKALL D and BURGER J (2003) Mythologies for assessing exposure to metals: speciation, bioavailability of metals and ecological factors. Ecotoxicol. Environ. Saf. 56 110-121.

PERRODIN Y, BABUT M, BEDELL JP, BRAY M, CLEMENT B, DELOLME C, DEVAUX A, DURRIEU C, GARRIC J and MONTUELLE B (2006) Assessment of ecotoxicological risks related to depositing dredged materials from canals in northern France on soil. Environ. Int. 32 804-814.

PERSOONE G, MARSALEK B, BLINOVA I, TÖRÖKNE A, ZARINA D, MANUSADZIANAS L, NALECZ-JAWECKI G, TOFAN L, STEPANOVA N, TOTHOVA L and KOLAR B (2003) A practical and user-friendly toxicity classification system with microbiotests for natural waters and wastewaters. Environ. Toxicol. 18 395-402.

PIOU S, BATAILLARD P, LABOUDIGUE A, FERARD JF and MASFARAUD JE (2009) Changes in the geochemistry and ecotoxicity of a $\mathrm{Zn}$ and $\mathrm{Cd}$ contaminated dredged sediment over time after land disposal. Environ. Res. 109 712-720.

POLISH COMMITTEE FOR STANDARDIZATION (2006) Geotechnical investigation and testing - Identification and classification of soil - Part 1, Part 2, PN-EN ISO 14 688-1, 2006 [in Polish].

POLISH COMMITTEE FOR STANDARDIZATION (1997). Soil Quality - Determination of pH. PN-ISO 10390; 1997 [in Polish].

POLISH COMMITTEE FOR STANDARDIZATION (1997) Solid wastes - Preparation of water extract. PN-Z-15009; 1997 [in Polish].

JOURNAL OF LAWS OF THE REPUBLIC OF POLAND NO. 55 ITEM 498 (2002) Regulation of the Minister of Environment from April 16th 2002 on the kinds and concentrations of substances which cause that the spoil is polluted, Warsaw.

PROKOP Z, VANGHELUWE ML, VAN SPRANG PA, JANSSEN CR and HOLOUBEK I (2003) Mobility and toxicity of metals in sandy sediment deposited. Ecotoxicol. Environ. Saf. 54 65-73.

RABAJCZYK A (2011) Reservoir recultivation versus forms of heavy metals in sediments: the case of the Kielce City Lake. Cent. Eur. J. Chem. $9357-366$. 
SABRA N, DUBOURGUIER H-CH and HAMIEH T (2012) Fungal leaching of heavy metals from sediments dredged from the Deûle Canal, France. Adv. Chem. Eng. Sci. 2 1-8.

SAHUQUILLO A, RIGOL A and RAURET G (2002) Comparison of leaching tests for the study of trace metals remobilisation in soils and sediments. J. Environ. Monit. 4 (6) 1003-1009.

SINGH KP, MOHAN D, SINGH VK and MALIK A (2005) Studies on distribution and fractionation of heavy metals in Gomati river sediments - a tributary of the Ganges, India. J. Hydrol. 312 14-27.

STEPHENS SR, ALLOWAY BJ, PARKER A, CARTER JE and HUDSON ME (2001) Changes in the leachability of metals from dredged canal sediments during drying and oxidation. Environ. Pollut. 114 407-413.
SZALIŃSKA E (2011) The Role of Sediments in the Assessment of Environmental Quality Continental Waters. Environmental Engineering Series No. 396. Cracow University of Technology, Cracow. 123 pp.

TACK FMG, CALLEWAERT O and VERLOO MG (1996) Metal solubility as a function of $\mathrm{pH}$ in contaminated dredged sediment affected by oxidation. Environ. Pollut. 91 199-208.

TROJANOWSKI J, TROJANOWSKA C and JAŃCZAK C (2007) Heavy metals migration in the system: near bottom water - interstitial water - bottom sediment in Gradno Lake. Baltic Coast. Zone $1183-101$.

YUVANATEMIYA V and BOYD CE (2006) Physical and chemical changes in aquaculture pond bottom soil resulting from sediment removal. Aquacult. Eng. 35 199-205. 